\title{
DINAMIKA PENANAMAN NILAI-NILAI BELA NEGARA KADET MAGUWO DALAM PERSPEKTIF HISTORIS
}

\author{
${ }^{1)}$ Yulianto Hadi, ${ }^{2)}$ Djoko Suryo, ${ }^{1)}$ F.X. Sudarsono \\ ${ }^{1)}$ Lanud Adisutjipto, ${ }^{2}$ Universitas Gadjah Mada, ${ }^{3)}$ Universitas Negeri Yogyakarta, \\ yulianto.hadi@yahoo.com, ${ }^{2)}$ djoko98@yahoo.com
}

Abstrak

Penelitian ini bertujuan untuk mengidentifikasi, mengetahui, memahami, dan menemukan: 1) formulasi nilai-nilai bela negara yang terkandung dalam peristiwa Serangan Fajar dan jatuhnya pesawat Dakota VT-CLA pada tanggal 29 Juli 1947; 2) dinamika interpretasi tokoh dan pejabat TNI AU terhadap bela negara; 3) rumusan dinamika proses penanaman nilai-nilai bela negara di Sekbang; 4) faktor-faktor yang berpengaruh terhadap dinamika penanaman nilai-nilai bela negara di Sekbang. Penelitian ini merupakan penelitian kualitatif yang menggunakan kombinasi dari berbagai pendekatan dan metode penelitian. Simpulan dari penelitian ini adalah: 1) core value bela negara Kadet Maguwo yang masih relevan; sesuai dengan landasan historis dan landasan filosofis pendidikan meliputi nilai-nilai kesetiaan dan kecintaan terhadap negara Indonesia dengan tetap didasari nilai-nilai ketuhanan, ketulusan, kekuatan tekad, kesatria, moralitas, keteladanan, integritas, profesionalitas, dan kedisiplinan; 2) bela negara awalnya bersifat filosofis, dan diperkuat secara ideologis untuk mengembangkan eksistensinya yang mengutamakan keberanian dengan integritas dan profesionalitas; 3) penanaman nilai diawali secara sederhana dengan landasan filosofis yang penuh makna, berlanjut dengan intensitas yang tinggi untuk pemantapan ideologis, dan psikologis, kemudian mengarah ke sosiologis yang intensitasnya menuru; 4) dinamika penanaman nilai-nilai bela negara dipengaruhi oleh faktor ekonomi, politik, zaman, dan budaya yang berada pada empat tingkatan, yaitu nasional/internasional, departemen, unit pelaksana, dan individu siswa. Proses penanaman nilai-nilai bela negara yang berpola behavioristik dan melibatkan kesadaran siswa untuk turut aktif dalam proses pendidikan akan berdampak sangat dalam, merasuk kedalam jiwa dan menjadi sikap hidup sepanjang hayat siswa, karena telah mencapai pada tataran titik kesadaran integral.

Kata kunci: Penanaman Nilai, dan Nilai Bela Negara.

\section{THE DYNAMICS OF KADETMAGUWO STATE DEFENSE VALUES INTERNALIZATION IN THE HISTORICAL PERSPECTIVE}

\author{
${ }^{1)}$ Yulianto Hadi, ${ }^{2)}$ Djoko Suryo, ${ }^{1)}$ F.X. Sudarsono \\ ${ }^{1)}$ Lanud Adisutjipto, ${ }^{2)}$ Universitas Gadjah Mada, ${ }^{3)}$ Universitas Negeri Yogyakarta, \\ 1)yulianto.hadi@yahoo.com, 2)djoko98@yahoo.com
}

Abstract

This research aims to identify, know, understand, and find: 1) the formulation of the state defense value contained in "Serangan Fajar" event and the crashing of Dakota VT-CLA aircraft on July 29th, 1997; 2) the dynamic of personnel and Indonesian Air Force official interpretation to the state defense; 3) the formulation of the dynamic of state defense values internalization process at Indonesian Air Force Flying School; 4) factors which have effect on the dynamic of state defense values internalization at Indonesian Air Force Flying School. This research is a qualitative research study using the combination of various research methods and approaches. The conclusions of the research are: 1) the relevant core values of Kadet Maguwo state defense suits with historical and philosophical education bases, consist of loyal and devotional valuestoward Indonesia which is still based on divine, sincere, strong will, noble, moral, model, integrity, professional, and discipline values. 2) previously, state defense only had a philosophic quality, and was strengthened ideologically to develop the existence which focuses on bravery with integrity and professionalism. 3) the values internalization was preceded modestly with deep philosophic base, extended with high intensity for ideologic and psycology stabilization, which later aimed at sociologic stabilization which decreases in intensity.4) the dynamic of state defense values internalization affected by economic, politic, era, and culture factors in four levels: national/international, department, unit manager, and student's individual. The state defense values internalization process, which patterned behaviouristically and involved the students' consciousness to be active in the educational process, would have deep effects, and became the students' life-long attitude because it had achieved in point level of integral consciousness.

Keywords: values internalization and state defense values 


\section{PENDAHULUAN}

Globalisasi dan suasana keterbukaan pascapemerintahan Orde Baru menyebabkan arus informasi dari segala penjuru dunia seolah tidak terbendung. Berbagai ideology dan budaya menarik perhatian generasi muda bangsa Indonesia, untuk dipelajari dan dicoba diterapkan dalam upaya ulang mencari jati diri bangsa. Salah satu dampak buruk dari globalisasi dan reformasi yang melanda Indonesia adalah memudarnya semangat nasionalisme dan kecintaan pada negara.

Rasa nasionalisme yang diwujudkan dengan sikap bela negara mulai memudar, menjadi seakan-akan bela negara hanya merupakan beban tugas militer. Perkembangan sosial yang begitu cepat menyebabkan sikap rasa cinta tanah air, jiwa patriotisme dan nasionalisme menjadi berkurang. Unsur-unsur bela negara kurang terimplementasikan dalam kehidupan masyarakat Indonesia. Kaum muda semakin banyak yang kurang faham dan kurang menjiwai terhadap permasalahan bela negara. Hal tersebut terjadi pada seluruh elemen bangsa, termasuk di lingkungan TNI dan Polri. Kondisi ini terjadi karena sistem penanaman nilai-nilai sejarah perjuangan belum optimal.

Di Angkatan Udara banyak anggota dan siswa yang belum memahami sejarah perjuangan Angkatan Udara. Peristiwa yang dianggap sejarah besar oleh Angkatan Udara seperti peristiwa "Serangan Fajar dan Jatuhnya Pesawat Dakota tanggal 29 Juli 1947" belum betul-betul difahami, baik sejarahnya maupun nilai-nilai yang terkandung dalam peristiwa tersebut. Hal itu terjadi karena pengajaran masih sebatas fakta saja, bukan makna di balik fakta.

Pra penelitian Disertasi tanggal 27 Oktober 2009, yang dilakukan dengan cara pengisian kuesioner dan wawancara terbatas dengan para siswa Sekbang di Lanud Adisutjipto menunjukkan bahwa mayoritas siswa belum cukup mengerti dan belum memahami peristiwa sejarah perjuangan para pahlawannya. Dari Siswa Sekbang (46 orang) yang sudah beberapa tahun hidup di lingkungan Angkatan Udara, hanya 7 orang yang faham, 2 orang masih terbatas dan 37 orang tidak faham. Karena mereka belum memahami sejarah perjuangan dan belum mengenal para pahlawannya maka mereka kurang memahami terhadap nilai-nilai yang harus mereka implementasikan pada setiap sikap dan tindakannya dalam menjalankan tugas. Nilainilai nasionalisme dan nilai-nilai bela negara semakin memudar, tidak semua dapat dicerminkan dengan baik oleh setiap anggota dan siswa.

Mengingat pentingnya sejarah peristiwa 29 Juli 1947, dan memperhatikan kenyataan ironis seperti dalam pra penelitian, serta adanya perbedaan pendapat yang berkembang dari pemerhati sejarah tentang cerita sesungguhnya yang terjadi. Maka kiranya perlu ada suatu penelitian untuk menelusuri kenyataan terjadinya peristiwa 29 Juli 1947, menggali nilai-nilai luhur dari peristiwa tersebut, menelusuri proses penanaman nilai-nilai bela negara di Sekbang dan dinamikanya yang terjadi.

\section{Hakekat Nilai}

Pada umumnya nilai merupakan sesuatu yang diiyakan dan selalu memiliki konotasi positif. Frondizi (1963, p.82) menjelaskan bahwa:

"...they are independent of goods, goods are valuable things. This independence includes every empirical form, values are apriori qualities. Independence refers not only to objects which exist in the world, but also to our reactions towards good and values. Values as independent qualities do not vary with thing."

Maknanya adalah nilai merupakan suatu kualitas yang tidak tergantung pada pembawanya, merupakan kualitas apriori. Tidak tergantungnya kualitas tersebut tidak hanya pada objek yang ada di dunia ini, melainkan juga tidak tergantung pada reaksi kita terhadap kualitas tersebut. Nilai sebagai kualitas yang independen tidak berbeda dengan benda. Hakikat nilai adalah sifat atau kualitas yang melekat pada "sesuatu", kenyataan yang "tersembunyi" dibalik kenyataan-kenyataan lainnya, dan nilai berada secara independen dari orang yang membuat penilaian itu sendiri.

Scheler (1954, p.259) menjelaskan tentang sumber nilai, bahwa nilai merupakan kualitas yang memiliki keberadaan secara objektif, tidak tergantung pada sikap dan ada tidaknya subjek, serta keberadaannya bersifat apriori, yang tidak tergantung pada hal-hal empiris. Nilai-nilai berada secara objektif 
dalam dunia nilai, serta memiliki ketersusunan satu sama lain secara hierarkis. Konteks kehidupan sosial, beberapa sumber nilai yang lainnya adalah dari keluarga, lingkungan atau kelompok, dan dari agama. Nilai dapat berasal melalui pengalaman yang didapat seseorang dari orang tuanya atau keluarganya. The values you hold are a key part of you see yourself. Until recently scientists belived that our value set is learnt from our parents (Patching, 2007, p. 33).

Kelebihan suatu nilai atas berbagai jenis nilai yang lain harus dipahami dengan preferensi yang merupakan kegiatan khusus kesadaran. Dari strukturnya, jenis nilai terdiri dari: 1) Kategori nilai dasar; 2) Kategori wilayah kajian; 3) Klasifikasi nilai; dan 4) Hirarki nilai (Mulyana, 2004, p. 79).

Lima kriteria nilai berdasarkan preferensi tersebut, yaitu keabadian nilai, divisibility (sifat dapat dibagi-bagi), dasar nilai, kedalaman kepuasan, dan relatifitas. Dari kriteria tersebut Scheler menjadikan hirarki nilai-nya diurutkan dari terendah yaitu; nilai kehidupan, nilai vital, nilai spiritual, dan nilai kerohanian/kekudusan/religius (Scheler, 1954, p.125). Nilai kerokhanian ini dapat dibedakan atas empat macam, yaitu nilai kebenaran (rasio), keindahan (estetika/ rasa), kebaikan moral (kehendak), dan religius (keyakinan).

Hubungannya dengan tingkah laku seseorang, nilai sebagai rambu atau pengendali tindakan. Nilai sebagai norma-norma moral, yaitu merupakan standar tingkah laku yang berfungsi sebagai kerangka patokan (frame of reference) dalam interaksi sosial. Rokeach (1969, p.160) menjelaskan “...a value is a standard or yardstick to guide actions, attitudes, comparisons, evaluations, and justifications of self and others." Nilai sebagai standar berfungsi untuk mengarahkan tingkah laku, sikap, pembandingan, evaluasi, dan pemaknaan mengenai diri sendiri dan orang lain. Terdapat dua makna, yaitu nilai sebagai pengarah tingkah laku/sikap manusia, dan nilai sebagai alat pembanding/evaluasi bagi kondisi seseorang dengan orang lain.

Nilai mengarahkan tindakan, memberi arti, tujuan hidup, dan seperti rel kereta api agar tidak lepas dari jalur perjalanan. Nilai, nilai yang benar-benar melekat pada diri seseorang adalah nilai yang tercermin dari intensitas dan frekuensi tindakan atau perilakunya. Di lingkungan masyarakat terdapat standar tingkah laku yang berfungsi sebagai kerangka patokan (frame of reference) interaksi sosial, pembatas subjektivitas pribadi, pemberi arah untuk membentuk kehidupannya, pemersatu kelompok sosial, dan sebagai petunjuk bertingkah-laku. Sehingga dalam diri individu muncul altruisme, yaitu rasa menerima secara ikhlas terhadap frame of reference. Dalam kehidupan sosial, nilai-nilai berfungsi sebagai pedoman/kendali untuk berperilaku, atau batasan bertindak.

\section{Nilai Bela Negara}

Bela Negara adalah tekad, sikap dan tindakan warga negara yang teratur, menyeluruh, terpadu dan berlanjut yang dilandasi oleh kecintaan pada tanah air, kesadaran berbangsa dan bernegara Indonesia, keyakinan akan kesaktian Pancasila sebagai ideologi negara (Basrie: 1998, p.8). Nasionalisme adalah tekat atau semangat dari setiap warga negara untuk menjaga dan mempertahankan bangsa dan negara-nya agar selalu meningkat rasa kenyamanan, keamanan dan kesejahteraannya serta terjamin kedaulatannya (Hardjosatoto, 1985, p.42). Kemudian Renan (1994, p.51) menjelaskan tentang pengertian bangsa adalah jiwa, suatu asas kerohanian yang ditimbulkan karena; kemuliaan bersama diwaktu lampau yang dari aspek ini bangsa dapat disebut sebagai suatu hasil historis; keinginan hidup bersama (le desir de vivre ensemble) diwaktu sekarang, jadi merupakan persetujuan atau solidaritas besar dalam bentuk tetap mempergunakan warisan dari masa lampau tersebut bagi waktu sekarang dan seterusnya.

Makna bangsa tidak lepas dari sejarah masa lalu, dari sejarah warga dan sejarah wilayahnya. Untuk itu sejarah tidak boleh dilupakan, karena ilmu sejarah sangat dibutuhkan dalam kehidupan. Hasil penelitian ilmu Sejarah pada akhirnya harus dapat dipakai sebagai norma untuk pedoman bagi menilai keadaan sekarang dan memperhitungkan segala sesuatu yang mungkin terjadi pada waktu yang akan datang (Tamburaka, 2002, p.5). Sejarah merupakan peristiwa masa lampau sebagai manifestasi dalam bentuk kejiwaan di mana satu kebudayaan membuat pertanggungjawaban mengenai masa silamnya. Kebudayaan terus-menerus mengalami pembentukan dan pembaharuan nilai-nilai, 
maka semua bentuk kebudayaan adalah dalam gerak perubahan. Tiap-tiap bentuk itu ditempatkan ke dalam proses perubahan, pembaharuan dan pembentukan. Sejarah itu berguna karena mengajar manusia untuk belajar dari kesalahan-kesalahannya dan mencontoh dari peristiwa-peristiwa yang bermanfaat. Mempelajari sejarah dapat membuat orang berjiwa bijaksana. Dapat semakin bijaksana jika beberapa pandangan teoritis diterapkan pada peristiwa-peristiwa (Mulder, 2000, p.19).

\section{Penanaman Nilai dan Dampaknya}

Nilai-nilai positif dari sejarah peristiwa masa lampau, perlu ditanamkan kepada siswa atau generasi penerus. Nilai bersifat dinamis, berubah sesuai perkembangan zaman yang terjadi. Supaya nilai-nilai tetap terpelihara dari generasi ke generasi maka perlu adanya proses internalisasi, proses revitalisasi dan proses pemeliharaan secara terus-menerus. Pewarisan nilai-nilai kehidupan dilakukan melalui media masyarakat dan melalui media pendidikan di sekolah. Keterikatan terhadap kelompok sosial masyarakat dialami seseorang sejak kecil. Keterikatan diwaktu kecil berawal munculnya rasa empati berkembang menjadi altruistik yaitu rasa ikhlas, tanpa pamrih untuk bersikap empati terhadap benda dan berkembang terhadap lingkungannya (Durkheim, 1990, p. 161).

Pada fase prekonvensional perilaku anak merupakan perilaku konatif yang akhirnya menuju volisional. Perilaku altruistik pada fase anak-anak mengarahkan belajar melakukan sesuatu dengan mengerjakannya. Untuk itu anak harus dirangsang kekuatannya dengan latihan yang efektif, sehingga lebih luas mengenal kelompok. Latihan yang efektif dan bersama kelompok hanyalah dapat dilakukan di sekolah. Karena di sekolah anak akan mendapatkan lingkungannya yang sesungguhnya, dan mendapatkan materi ajaran lainnya. tentang isi ajarannya, pada zaman yang lebih maju direncanakan dalam program pendidikan. Education is the socialization of the younger generation. Pendidikan merupakan media bagi generasi muda untuk sosialisasi (Falconnet, 1923, p.529).

Pendidikan memiliki peran yang strategis dalam pola perkembangan moral. Tanpa landasan pendidikan, manusia akan banyak dikendalikan oleh dorongan kebutuhan biologisnya ketika hendak menentukan tindakan.
Sekolah memiliki peran yang besar dalam perkembangan moral anak. Fott $(2009$, p,7) menyampaikan:

"Education is the growth of mental powers, where growth has involves the increasing harmonization of individuals with society. That harmonization must respect the uniqueness of each person and his capacity for intellegence. Education aims to develop a model democratic society."

Dewey menjelaskan bahwa, "Education is a means toward the social continuity of life. It is part of every social group. School are one means of conducting education. Which should simplify and purify the student's environment (Fott, 2009, p,8)". Pendidikan merupakan cara menuju kelangsungan kehidupan sosial. Pendidikan merupakan bagian dari kelompok sosial. Sekolah merupakan salah satu media pendidikan, yang harus menyederhanakan dan memurnikan lingkungannya.

Secara filosofis nilai berperan sebagai jantung semua pengalaman ikhtiar pendidikan (as the heart of all educational experiences). Nilai berfungsi sebagai penggerak tindakan pendidikan, seperti halnya jantung yang memompa darah ke seluruh bagian tubuh, sehingga manusia hidup dan dapat berbuat. Sebagai landasan pendidikan nilai adalah terdiri dari empat landasan yaitu; landasan filosofis yang mengetengahkan akar pemikiran tentang hakikat manusia dari perspektif filsafat; landasan psikologis menjelaskan aspek-aspek psikis manusia sebagai individu; landasan sosiologis meliputi prinsip-prinsip pengembangan manusia sebagai anggota masyarakat landasan estetik; menguraikan kemampuan manusia dalam mempersepsi nilai keindahan (Mulyana, 2004, p.124).

Untuk menghasilkan lulusan yang mampu membuat keputusan moral dan memiliki perilaku yang terpuji perlu pendekatan komprehensif dan pembinaan terus-menerus dalam proses pendidikan nilai dan moral. Sebagaimana dikemukakan oleh Kirschenbaum (1995, p.31):

A comprehensive values education utilities many of the methods and activities from the value realization, character education, citizenship education, and moral edu-cation movements to help young 
people lead personally satisfying and socially constructive lives."

Dari segi metode pendekatan komprehensif meliputi: inkulkasi (inculcation), keteladanan (modeling), fasilitasi (facilitation), dan pengembangan keterampilan (skill building). Sedangkan dalam filsafat pendidikan, nilai ditempatkan sebagai bagian yang tidak terpisahkan dari upaya pendewasaan manusia melalui tindakan-tindakan pendidikan.

Fungsi pendidikan salah satunya adalah sebagai media penanaman nilai. Khususnya mengenai filosofi pendidikan dengan pendekatan sistem-sistem formal. Guru adalah pencipta lingkungan pendidikan siswa dan merupakan sumber ilham bagi siswa. Sebuah cara yang penting dan berharga dimana tanggapan siswa dilahirkan adalah melalui kegiatan yang bersifat meniru (imitative) khususnya jika diarahkan oleh para panutan dalam hal karya kreatif serta kepribadian guru yang budiman (O'Neil, 2008, p.14). Hal yang sangat penting dalam pendidikan adalah mengembangkan keterampilan siswa dalam melakukan proses menilai. Guru bukan sebagai pengajar nilai, melainkan sebagai role model dan pendorong.

Mengenai perilaku dan proses pembinaan maka terkait dengan behaviorisme. Ada tiga perilaku dasar yaitu, perilaku Konatif, Volisional, dan Normatif. (O'Neil, 2008, p.49). Perilaku berkaitan dengan sikap dan niat, sikap dan keyakinan akan membentuk perilaku melalui niat. Sikap akan membentuk perilaku seseorang, tetapi norma subjektif seseorang berpengaruh besar kepada niat untuk membentuk perilaku. Dengan demikian perilaku terbentuk oleh niat yang dipengaruhi oleh sikap dan norma subjektif lingkungannya (Fishben, 1975, p.16).

Upaya pembinaan terhadap siswa dalam mengimplementasikan nilai-nilai selama ini yang terjadi adalah berawal dari adanya nilai-nilai yang berlaku dalam kelompok sekitarnya. Kemudian sampai pada setiap siswa melalui pembinaan ataupun pengalaman, sehingga muncul suatu persepsi dan motivasi untuk bertindak dalam berbagai aspek kehidupan. Setiap tindakan yang muncul dalam aspek kehidupan tersebut akhirnya kembali mewarnai nilai-nilai dalam kelompoknya dan apabila diterima maka akan menjadi nilai-nilai yang berlaku dalam kelompok tersebut.
Membela negara adalah menjadi janji utama anggota TNI sejak dalam proses seleksi masuk. Membela negara adalah menjadi tugas pokok anggota TNI yang realisasinya disesuaikan dengan matranya masing-masing. Anggota TNI AU membela negara dengan menegakkan kedaulatan negara di wilayah yurisdiksi dirgantara negara Indonesia. Sesuai dengan UURI nomor 3 tahun 2002, tentang Pertahanan Negara; UURI nomor 25 tahun 2004 tentang Sisrenbangnas; UURI nomor 34 tahun 2004 tentang TNI. Dijabarkan dengan Peraturan Panglima TNI nomor: Perpang/45/VI/2010 tanggal 15 Juni 2010 tentang Doktrin TNI Tridarma Eka Karma (Tridek). Tugas Pokok Angkatan Udara tertuang dalam UURI nomor 34 tahun 2004 tentang TNI telah dijabarkan dalam Keputusan Kepala Staf TNI AU nomor: Kep/22/VII/2004 tanggal 29 Juli 2004 tentang Doktrin TNI AU Swa Bhuwana Pakca.

Pelaksanaannya dijabarkan dengan Perkasau nomor: Perkasau/89/X/2009 tanggal 12 Oktober 2009 tentang Pokok-pokok Organisasi dan Prosedur TNI AU. Untuk aplikasinya setiap unsur terkecil dalam satuan atau tim diatur dalam buku Juklak dan Juknis serta Protap. Sedangkan dilingkungan pendidikan TNI AU, pelaksanaannya dibawah kendali Lembaga Pendidikan Kodikau sebagai Kotama Fungsional TNI AU. Operasionalisasi nilai bela negara dalam lembaga pendidikan TNI AU dibawah pembinaan Kodikau. Demikian juga untuk lembaga pendidikan Sekolah Penerbang TNI AU yang dilaksanakan di Lanud Adisutjipto. Untuk penanaman dan pewarisan nilai-nilai bela negara terhadap siswa Sekbang dilaksanakan melalui kurikulum, dan pembinaan seperti tradisi pembinaan khas Sekbang dan tradisi Lanud Adisutjipto.

Penanaman nilai bela negara diharapkan dapat berdampak terus tertanam dan berkembang dengan baik dalam jiwa siswa. Nilai dapat terpelihara dengan baik oleh individu apabila individu tersebut memiliki kesadaran yang baik terhadap nilai-nilai. Kesadaran nilai akan terjaga apabila setiap individu telah mencapai kesadaran integral. Empat Quadrant manusia dalam kesadaran, yaitu intentional, behavioural, cultural, and Social. Dari pengalaman indera, pengalaman kejiwaan, dan pengalaman religius akan muncul kesadaran diri. kesadaran itu berlang- 
sung dari mata secara fisik (eye of flesh) menuju mata pikir (eye of mind) dan berakhir pada mata hati (eye of contemplation). Kesadaran inilah yang dimaksud sebagai "Kesadaran Integral", yaitu kesadaran yang melibatkan seluruh fungsi indra dan mental manusia (Wilber: 1997, p.23).

\section{Faktor yang Mempengaruhi Dinamika Proses Penanaman Nilai}

Dalam kehidupan sosial setiap nilai tidak akan memiliki arti yang konstan sepanjang masa, tetapi nilai akan selalu bersifat dinamis. Nilai akan selalu berubah seiring dengan perkembangan yang terjadi. Makna dari nilai tertentu pada zaman sekarang berbeda dengan makna nilai pada zaman dahulu meskipun objeknya sama. Perubahan-perubahan akan selalu terjadi, demikian pula pada proses penanaman nilai bela negara. Tentu akan terjadi dinamika dalam persepsi terhadap nilai mana yang diberlakukan dan yang bisa diterima oleh kelompok. Dinamika persepsi bela negara dan dinamika proses internalisasi akan dipengaruhi oleh berbagai faktor, sesuai perkembangan yang terjadi.

Perubahan politik suatu negara akan membawa dampak yang sangat signifikan terhadap segala aspek kehidupan rakyatnya. Semakin radikal perubahan politik itu maka akan semakin ekstrim juga dampaknya. Perubahan politik dan kebijakan tersebut berdampak terhadap perubahan persepsi massa tentang nilai-nilai kehidupan. Perubahan persepsi akan berdampak terhadap susunan atau struktur sosial masyarakat, budayanya, dan terhadap perkembangan perekonomian (Ritzer: 2009, p.7). Revolusi bidang ekonomi berdampak terjadinya perubahan nilai-nilai kehidupan yang berkembang dalam masyarakat. Perubahan sistem ekonomi membawa perubahan dan pergeseran tatanan nilai kehidupan masyarakat (Ritzer: 2009, p.7).

Kultur dalam struktur sosial akan berubah sesuai dengan perkembangan persepsi anggotanya terhadap budayanya dalam menghadapi tuntutan dinamika. Struktur sosial dapat berubah terlebih dahulu, apabila terjadi perubahan persepsi. Sedangkan perubahan persepsi dapat terjadi sebelum proses transformasi sosial, transformasi sosial oleh masyarakat akan merubah struktur sosial (Freire: 2007, p.79). Demikian seterusnya bahwa setiap terjadi perubahan struktur sosial (Social Stucture) akan membawa perubahan Kultur (Social Culture), perubahan budaya akan berdampak perubahan pemberlakuan nilai-nilai dalam pranata kehidupan baru.

\section{METODE PENELITIAN}

Penelitian kualitatif ini berdesain studi kasus terhadap peristiwa 29 Juli 1947, yang menggunakan beberapa pendekatan. Untuk memahami segala sesuatu yang telah lewat dan untuk menelusuri terjadinya peristiwa 29 Juli 1947 maupun perkembangan pendidikan Sekbang menggunakan pendekatan histori. Kemudian untuk memahami filosofi interprettasi data dan dari subjek penelitian menggunakan pendekatan phenomenologi.

Penelitian dilaksanakan terpusat di Lanud Adisutjipto khususnya di lingkungan Sekbang, karena lingkungan Lanud Adisutjipto merupakan tempat terjadinya peristiwa. Untuk memperdalam mengenai proses penanaman nilai, pelaksanaan penelitian fokus di lingkungan kampus maupun di mess, yaitu di lingkungan Wingdik Terbang, di SkadikSkadik, khususnya di Skadik 104, dan di Mess Wirambara.

Untuk mendapatkan data lain yang tidak didapatkan di Lanud Adisutjipto dicari di tempat lain yang memungkinkan, antara lain di Ruang Arsip dan Dokumen Lanud Adisutjipto, Perpustakaan Skadik 104 Lanud Adisutjipto, dan di kantor Penerangan dan Perpustakaan Lanud Adisutjipto. Pencarian data juga dilakukan dengan penelusuran arsip dan dokumen ke Yogyakarta Library Center, Monumen Pers Solo, dan Museum Pusat TNI AU.

Pelaksanaan pencarian data ke tempat penelitian atau ke para subjek penelitian waktunya atau jam penelitiannya tidak tertentu, tetapi menyesuaikan dengan kebutuhan dan kesediaan para subjek sebagai sumber data. Penelitian dimulai pada bulan Februari 2012, setelah mendapat ijin dari Komandan Lanud Adisutjipto.

Subjek dalam penelitian ini terdiri dari beberapa kelompok yaitu; kelompok veteran dan sesepuh untuk memahami lintasan sejarah dan proses penanaman nilai pada masa lalu; kelompok tokoh dan pejabat yang pernah menjadi Komandan Lanud Adisutjipto untuk memahami dinamika persepsi bela negara dan memahami dinamika proses penanaman bela 
negara; kelompok Instruktur Penerbang untuk memahami perkembangan proses penanaman bela negara, staf dan siswa untuk memahami tindakan pembinaan dan perubahan perilaku pascapembinaan.

Data dikumpulkan melalui pengamatan partisipatif, wawancara mendalam, dan analisis dokumen. Untuk keabsahan data dilaksanakan perpanjangan waktu dan dilakukan trianggulasi sumber maupun trianggulasi teknik, serta audit trail. Data dianalisis dengan teknik analisis kualitatif yang bergerak secara interaktif terus-menerus antara pengumpulan data, reduksi data, penyajian data, dan kesimpulan.

Dalam konteks penelitian ini dilakukan melalui proses; (1) Pengumpulan data selengkap mungkin terkait dengan tema penelitian; (2) Reduksi data meliputi proses-proses pemilihan dan pemfokusan, penyederhanaan data, pengabstraksian, dan merefleksikan sesuai tema; (3) Penyajian data yang telah direduksi, diorganisasikan dan dikelompokkan untuk memudahkan membuat deskripsi dan kesimpulan; (4) Kesimpulan dan verifikasi, menginterpretasikan atau memaknai data dari hasil penelitian. Membuat simpulan dengan pengelompokan data, menemukan pola makna yang sesuai dengan tema penelitian yaitu "Dinamika Penanaman Nilai Bela Negara Kadet Maguwo". Kemudian melakukan review, penelusuran dan auditing data untuk menguji ulang kebenaran, kecocokan, dan kekokohan data yang terkumpul.

\section{HASIL PENELITIAN DAN PEMBAHASAN}

\section{Formulasi Nilai-Nilai Bela Negara}

Ditelusuri berbagai sumber data yang diantaranya adalah berupa artefak, dokumen, dan informan dari tokoh-tokoh dan pejabat. Penelusuran mengungkap banyak nilai-nilai kehidupan dari berbagai macam sumber yang ditanamkan menjadi pedoman bersikap dan berperilaku bagi siswa Sekbang. Sumbersumber nilai yang diperoleh dikelompokkan menjadi tiga, yaitu; 1) Formulasi "A": interpretasi dari artefak dan pedoman sikap perilaku siswa; 2) Formulasi "B": nilai sesuai kedudukan TNI; 3) Formulasi "C": interpretasi bela negara dari informan. Nilai-nilai dari berbagai sumber tersebut di pilah-pilah dan dikelompokkan berdasarkan hirarki nilai, kemudian dikelompokkan sesuai dengan unsur-unsur utama hakekat bela negara, dan nilai-nilai yang serumpun disatukan.

Nilai-nilai formulasi A terdiri dari: 1) Unsur menjaga dan mempertahankan negara: religi/ketaqwaan, patriotik/kecintaan tanah air, kesetiaan, dan kesatria; 2) keamanan negara: kedisiplinan, kewaspadaan, kesiapsiagaan, dan kerahasiaan; 3) kedaulatan negara: profesionalitas, keteladanan, kekuatan tekad, ketulusan, dan tanpa pamrih; 4) tujuan hidup bernegara: bertindak secara prioritas, kesederhanaan, kebersamaan, dinamis. Formulasi B yaitu: 1) sebagai bangsa: kesetiaan, kesatria, kekuatan tekad, kewaspadaan, kesiapsiagaan, dan kerahasiaan.; 2) sebagai warga negara: kecintaan tanah air, kesatria, keteladanan, tanpa pamrih, moralitas.; 3) sebagai pribadi: ketuhanan, profesionalitas, kekuatan tekad, tanpa pamrih, kesatria, kesederhanaan, dan kedisiplinan. Formulasi $\mathrm{C}$ terdiri dari nilai ketuhanan, kesetiaan, kesatria, kekuatan tekad, ketulusan, moralitas dan keteladanan, profesionalitas, kedisiplinan.

Ketiga formulasi tersebut digabungkan menjadi satu, sehingga terdapat kumpulan nilai yang sama. Berbagai nilai yang sama tersebut diyakini sebagai nilai yang dapat diterima oleh ketiga sumber sebagai cerminan dari komunitasnya, dan merupakan nilai-nilai yang relevan. Sedangkan nilai yang tidak sama merupakan nilai-nilai luhur yang tetap harus dilestarikan. Proses penggabungan ketiga formulasi tersebut diasumsikan dengan penggabungan tiga lingkaran A-B-C, yang menghasilkan wilayah arsiran diantara ketiga lingkaran tersebut. Selanjutnya wilayah arsiran tersebut ditandai dengan huruf " $\mathrm{X}$ " sebagai simbul kelompok nilai yang relevan. Proses penggabungan lingkaran tersebut sebagaimana yang terlihat pada gambar 1 .

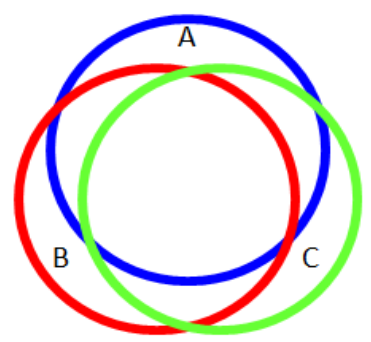

Gambar 1. Formulasi Nilai Bela Negara yang masih relevan

Sumber: Hasil analisis formulasi nilai bela negara.

Nilai bela negara Kadet Maguwo yang masih relevan dan perlu di wariskan kepada 
generasi penerus adalah nilai-nilai kesetiaan dan kecintaan terhadap negara Indonesia dengan tetap didasari nilai-nilai ketuhanan, ketulusan, kekuatan tekad, kesatria, moralitas, keteladanan, profesionalitas, dan kedisiplinan. Sedangkan nilai-nilai lainnya tetap merupakan nilai-nilai luhur yang perlu terus dilestarikan. Karena dinamika setiap masa atau zaman tidak sama, sehingga kebutuhan terhadap nilai-nilai juga berkembang dan berubah seiring dengan perubahan zaman itu sendiri. Nilai-nilai yang sekarang relevan belum tentu bertahan tetap relevan pada masa yang akan datang. Demikian juga sebaliknya bahwa nilai-nilai yang sekarang kurang relevan, pada masa yang akan datang dapat berubah menjadi relevan untuk diaplikasikan.

\section{Dinamika Persepsi Bela Negara}

Data persepsi bela negara diperoleh dari interpretasi tokoh terhadap unsur-unsur bela negara yang diantaranya yaitu ketakwaan, kekuatan tekad, berani, semangat juang, pengabdian, tanpa pamrih, pantang menyerah, rela berkorban, integritas, profesionalitas, dan kebersamaan. Kemudian data-data dari reinterpretasi terhadap artefak dan dokumen terdiri dari nilai-nilai semangat kejuangan, jiwa sapta marga, ketaqwaan, berani bersikap, tampil gagah, profesionalitas, dan integritas. Sumber data dari artefak dan dokumen selain di analisis secara phenomenologi juga dilakukan pendekatan historis yaitu berdasar deret waktu. Data-data di kelompokkan menjadi per dekade, mulai dari tahun 1950-an sampai dengan tahun 2000-an. Kedua sumber data yang mengandung nilai-nilai tersebut digabungkan sebagaimana pola analisis pada tema pertama, sehingga diperoleh kesimpulan yang meliputi nilai-nilai bela negara. Selanjutnya nilai-nilai bela negara tersebut, dirangkai menjadi sebuah kalimat pernyataan menjadi definisi yang baru dari makna bela negara.

Dinamika persepsi tokoh dan pejabat TNI AU terhadap bela negara awalnya bersifat filosofis dan diperkuat secara ideologis dalam mengembangkan eksistensi TNI AU. Hal ini ditunjukkan dengan berbagai artefak, dokumen, dan interpretasi informan yang mengutamakan nilai-nilai keberanian dengan integritas dan profesionalitas. Bela negara adalah sikap semangat kejuangan pantang menyerah setiap individu, dengan keimanan, ketaqwaan dan integritasnya berniat tekad bulat tanpa pamrih berani rela berkorban untuk negara secara profesional bersama-sama mencapai kejayaan NKRI yang aman berlandaskan Pancasila dan UUD 1945.

\section{Dinamika Proses Penanaman Nilai Bela Negara}

Dinamika kondisi suatu lembaga atau wilayah tertentu dapat terjadi oleh berbagai aspek kehidupan yang mempengaruhinya. Dinamika proses penanaman nilai-nilai bela negara di Sekbang ditelusuri melalui sumber data artefak, dokumen, dan informan. Sumber artefak dan dokumen dicari fungsi dan maknanya, untuk itu juga dilakukan reinterpretasi terhadap artefak yang dibagi sesuai deret waktu per-dekade. Demikian pula interpretasi dari informan terhadap proses penanaman nilai bela negara yang mereka alami, yang mereka lakukan dan yang mereka ketahui dikelompokkan per-dekade sesuai kelompok senioritas yaitu generasi tahun 1950-an, 1960-an, 1970-an, 1980-an, 1990-an, dan 2000-an.

Dari kajian analisis data terungkap bahwa tujuan penanaman nilai-nilai bela negara Kadet Maguwo adalah untuk melestarikan nilai-nilai luhur bangsa dan untuk memberikan warna karakter perilaku para Perwira Penerbang sesuai dengan nilai-nilai bela negara Kadet Maguwo. Sedangkan fungsi artefak adalah sebagai media pengingat, sebagai petunjuk kepada para generasi penerus bahwa pernah terjadi peristiwa bersejarah, dan sebagai media penanaman nilai-nilai luhur dan nilai-nilai bela negara Kadet Maguwo kepada generasi penerus. Nilai-nilai bela negara yang dicerminkan pada masa lalu terdiri dari nilai keikhlasan, semangat juang yang tinggi, kebulatan tekad untuk berjuang mencapai tujuan negara, dan rela berkorban. Sedangkan sekarang makna yang tersirat adalah, dalam bela negara harus dilandasi dengan keimanan dan ketaqwaan, berani tampil gagah, dan profesionalitas dalam menyelesaikan tugasnya demi kejayaan negara, tanpa menghilangkan nilai-nilai luhur sebelumnya.

Domain yang menjadi pokok kajian internalisasi adalah proses penyampaian, dan makna bela negara yang tercermin dalam kegiatan. Dinamika yang terungkap tentang proses pelaksanaan penanaman nilai-nilai bela negara di Sekbang Lanud Adisutjipto, adalah sebagai berikut. 
a. Tahun 1950-an sampai dengan 1960-an proses pendidikan dilaksanakan secara sederhana tanpa buku sejarah dan belum termasuk dalam kurikulum. Penanaman nilainilai bela negara Kadet Maguwo diekspresikan dengan lambang, simbol, monumen, dan prasasti. Instruksi pelak-sanaan melalui keteladanan, santiaji, cerita-cerita, dan pembinaan kejuangan secara pisik. Makna cerminan unsur-unsur bela negara yang muncul yaitu keikhlasan, semangat juang yang tinggi, kebulatan tekad untuk berjuang mencapai tujuan negara, dan rela berkorban.

b. Tahun 1970-an pendidikan Sekbang menjadi kesatuan dalam program pendidikan Taruna, sehingga melibatkan hirarki senioritas di Taruna dengan pembinaan kejuangan secara pisik menjadi semakin ketat dan keras. Makna bela negara yang terkandung terdiri dari nilai-nilai sifat kebajikan, kebenaran, berkarakter, setia, loyal, berdedikasi, patriotik/cinta tanah air, kerelaan berkorban, kesatria, keper-wiraan, kewaspadaan, kesiapsiagaan, profesionalitas dan moderen, serta keteguhan mencapai cita-cita luhur kejayaan negara.

c. Tahun 1980-an terdapat beberapa tambahan kegiatan, sehingga intensitasnya meningkat lebih tinggi. Beberapa tambahan kegiatan lainnya yang bersifat temporer yaitu kegiatan "Sarasehan" pada tanggal 28 Juli malam dan "Napak Tilas Serangan Fajar", tradisi "Masuk Mess Wirambara", dan tradisi "Pengambilan Wing Penerbang". Kegiatan-kegiatan tersebut sampai dengan akhir 1990-an tetap dilaksanakan. Makna nilai-nilai bela negara yang terkandung antara lain, nilai totalitas, kesetaraan derajat, kebersamaan, patriotik, kepahlawanan, keihklasan, rela berkorban, tanpa pamrih dalam berjuang, dan profesionalitas untuk mencapai cita-cita kejayaan negara.

d. Tahun 2000-an kegiatannya tetap stabil, namun intensitasnya menurun dan cenderung lebih ringan. Terungkap bahwa terdapat perubahan dari sisi kebijakan yaitu mengenai proses rekruitmen. Pada tahun 2002 terjadi perubahan kurikulum yang bersifat ideologis dan memperkuat kembali penghayatan Pancasila dan UUD 1945. Hal tersebut menjadikan lebih komunikatif dan ber-tindak secara persuasif dengan mengutamakan integritas dan profesional.

\section{Faktor-Faktor yang Mempengaruhi Dinamkia Proses Penanaman Nilai-Nilai Bela Negara}

Terjadi dinamika karena kehidupan selalu berubah karena adanya perbedaan waktu dan tempat. Manusia tidak dapat meramalkan nilai yang sesuai untuk generasi yang akan datang. Setiap generasi mempunyai hak untuk menentukan nilainya sendiri, untuk itu yang perlu diajarkan kepada generasi muda bukan nilai-nya, melainkan proses untuk dapat menemukan nilai-nilai mereka sendiri sesuai dengan tempat dan zamannya. Proses penanaman nilai, inculcation approach merupakan pendekatan yang memberi penekanan pada penanaman nilai-nilai sosial dalam diri siswa. Dengan penanaman nilai-nilai menjadikan siswa lebih siap menghadapi perubahan-perubahan yang akan ditemuinya.

Sesuai dengan teori yang dikemukakan oleh Ritzer, Giddens, dan Freire, penelitian ini menemukan dinamika proses pelaksanaan penanaman nilai-nilai bela negara Kadet Maguwo terhadap siswa Sekbang. Melalui observasi, dan interpretasi informan terungkap bahwa faktor-faktor yang mempengaruhi adalah perkembangan politik negara, perkembangan ekonomi bangsa, perkembangan zaman, perkembangan teknologi informasikomunikasi, dan globalisasi yang mempengaruhi lingkungan strategis, sehingga berdampak terhadap keputusan atau kebijakan pimpinan dalam menentukan dan mengarahkan perubahan budaya di lingkungan Sekbang. Perubahan-perubahan tersebut dari sisi makna dalam pendidikan nilai bukan merupakan perubahan yang mendasar. Perubahan bukan pada aspek filosofis pendidikan tetapi bentuk kegiatan dan cara penyampaiannya. Perubahan mengarah kepada landasan psikologis dan sosiologis.

Berbagai faktor tersebut berasal dari empat tingkatan, yaitu tingkat nasional dan internasional, tingkat TNI atau Matra TNI AU, tingkat Kesatuan yaitu Lanud Adisutjipto, dan individu siswa. Empat tingkatan tersebut dikelompokkan menjadi dua, yaitu sumber internal dan eksternal. Maknanya adalah, bahwa setiap perubahan yang menjadi dinamika bagi proses penanaman nilai-nilai bela negara di Sekbang disebabkan oleh faktor internal dan faktor eksternal. Faktor internal dapat dikarenakan oleh potensi-potensi yang melekat dan dibawa oleh siswa Sekbang atau 
potensi yang melekat dan berkembang di Lanud Adisutjipto. Sedangkan faktor eksternal adalah faktor yang bersumber dari tingkat nasional dan internasional, yaitu kondisi yang di tingkat Mabes TNI, Mabes TNI AU, dan Negara Indonesia maupun kondisi regional dan internasional.

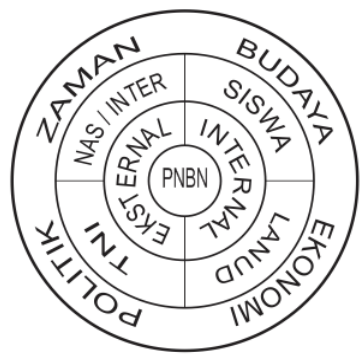

Gambar 2. Faktor yang mempengaruhi dinamika PNBN

Sumber: Hasil analisa faktor yang mempengaruhi perubahan proses $P N B N$ di Sekbang

Besarnya pengaruh dari tiap-tiap faktor terhadap proses penanaman nilai-nilai bela negara di Sekbang berbeda-beda. Faktor ekonomi sangat besar pengaruhnya terhadap pelaksanaan penanaman nilai-nilai bela negara. selanjutnya secara berturut-turut adalah faktor politik, faktor perkembangan zaman (globalisasi dan lingkungan strategis), dan faktor budaya. Tingkatan keberpengaruhan faktorfaktor tersebut sebagaimana yang nampak pada Gambar 2.

Proses kegiatan penanaman bela negara di Sekbang seperti yang digambarkan dalam teori Wilber. Para siswa dalam mengikuti proses penanaman bela negara mencapai pada tataran kesadaran integral, yaitu kesadaran yang melibatkan seluruh fungsi indra dan mental manusia, sebagaimana nampak pada Gambar 3. Kesadaran siswa diperoleh karena siswa melihat, dan melakukan sendiri secara langsung terhadap kegiatan proses penanaman nilai-nilai bela negara.

Kesadaran siswa dimulai dari mata secara fisik (eye of flesh), yang langsung melihat dan mengalami, sehingga menjadi pengalaman yang diteruskan ke ranah pikir dan menjadi mata pikir (eye of mind) bagi setiap tindakan. Dari pengalaman menjadi pemikiran dan bertindak. Dari tindakantindakannya pasti akan timbul suatu reaksi. Lepas dari positif dan negatif reaksi tersebut, maka akan menjadi bahan renungan dan sebagai pertimbangan dalam berbagai hal. Sehingga nilai-nilai yang telah diterima dari proses penanaman nilai-nilai bela negara tersebut menjadi kesadaran mata hati (eye of contemplation) yang senantiasa melekat dalam jiwa siswa.

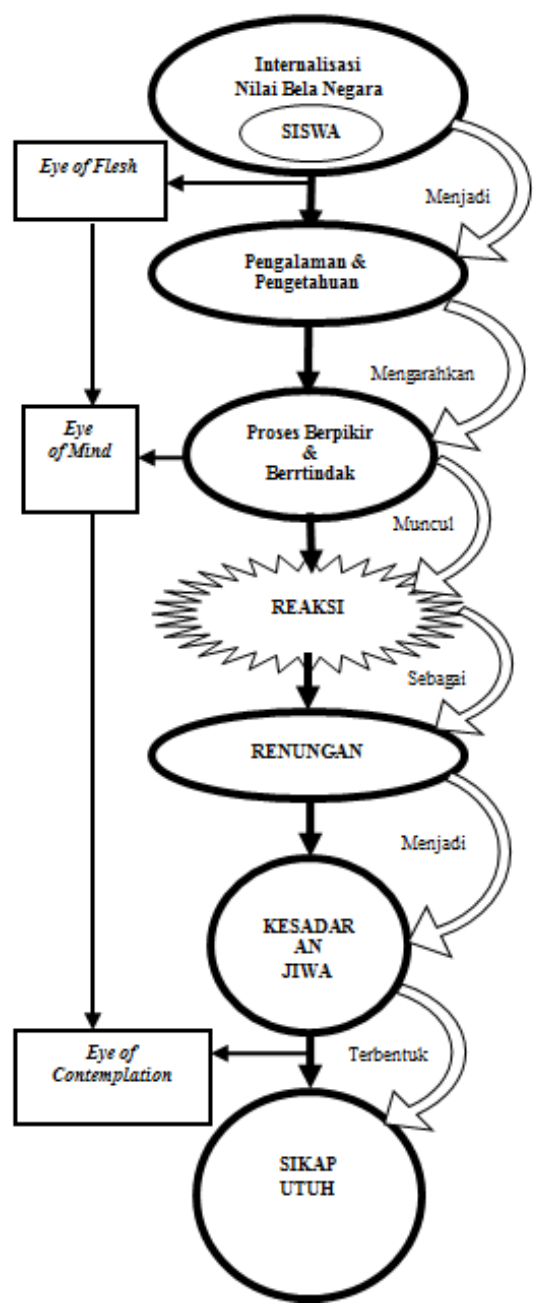

Gambar 3. Proses Terbentuknya Kesadaran Integral Siswa

Sumber: Simpulan dari proses PNBN di Sekbang

Kesadaran integral tersebut yang sesungguhnya telah terjadi pada diri para siswa, seperti yang diungkap oleh beberapa informan. Sehingga segala nilai-nilai bela negara yang telah tertanam dalam diri para siswa Sekbang tidak luntur dan tidak hilang selama-lamanya. Karena para siswa benarbenar telah melalui tiga proses kesadaran integral seperti teori Wilber. Kesadaran integral juga disebabkan oleh karena terjadinya perubahan tingkat pendidikan mereka yang cenderung berpengaruh terhadap pergeseran nilai-nilai kehidupan. Para alumni telah melintasi berbagai jenjang pengalaman 
hidup, sehingga membawa dampak perubahan atau pergeseran nilai-nilai kehidupan yang diberlakukannya. Karena orang terdidik cenderung lebih lama berada dalam pembinaan sekolah yang merupakan tempat penanaman nilai-nilai dan sebagai salah satu media untuk mewariskan nilai-nilai.

\section{SIMPULAN DAN SARAN}

\section{Simpulan}

Core value bela negara Kadet Maguwo yang masih relevan, sesuai dengan landasan historis dan landasan filosofis pendidikan meliputi nilai-nilai kesetiaan dan kecintaan terhadap negara Indonesia yang tetap didasari nilai-nilai ketuhanan, ketulusan, kekuatan tekad, kesatria, moralitas, keteladanan, integritas, profesionalitas, dan kedisiplinan.

Persepsi tokoh dan pejabat TNI AU terhadap bela negara awalnya bersifat filosofis dan diperkuat secara ideologis dalam mengembangkan eksistensi TNI AU. Hal ini ditunjukkan dengan berbagai artefak, dokumen, dan interpretasi informan yang mengutamakan nilai-nilai keberanian dengan integritas dan profesionalitas. Bela negara adalah sikap semangat kejuangan pantang menyerah setiap individu, dengan keimanan, ketaqwaan dan integritasnya berniat tekad bulat tanpa pamrih berani rela berkorban untuk negara secara profesional bersama-sama mencapai kejayaan NKRI yang aman berlandaskan Pancasila dan UUD 1945.

Proses penanaman nilai bela negara di Sekbang memperkuat pemantapan ideologis, psikologis, dan mengarah ke sosiologis. Dinamika tersebut menjadikan TNI AU lebih komunikatif dan bertindak secara persuasif, dengan mengedepankan integritas dan profesionalitasnya. Pendidikan berawal secara sederhana dengan landasan filosofis yang penuh makna, kemudian memperkuat aspek psikologis dan ideologis. Selanjutnya mengarah ke sosiologis, sehingga intensitas pembinaannya cenderung menurun.

Dinamika proses penanaman nilai-nilai bela negara terjadi karena kebutuhan nilainilai berkembang dan berubah selaras dengan perubahan zaman dan berbagai aspek yang mempengaruhinya, antara lain faktor ekonomi, politik, zaman, dan budaya yang berada pada empat tingkatan, yaitu nasional/internasional, TNI/TNI AU, Kesatuan Lanud
Adisutjipto, dan individu siswa. Penanaman nilai-nilai bela negara yang berpola behavioristik dan melibatkan kesadaran siswa untuk turut aktif dalam proses pendidikan berdampak besar ke dalam jiwa siswa dan menjadi sikap hidup sepanjang hayat mereka. Kondisi itu dikarenakan telah mencapai pada tataran titik kesadaran integral yang melibatkan seluruh fungsi indra dan mental siswa, melalui proses kesadaran langsung dari mata secara fisik (eye of flesh), menjadi eye of mind, dan berakhir pada eye of contemplation bagi setiap tindakan.

\section{Saran}

Terungkap bahwa meskipun frekuensi kegiatannya stabil tetapi terjadi penurunan intensitas pembinaan. Juga ditemukan adanya hal yang kontradiksi, yaitu interpretasi makna bela negara pejabat TNI AU yang mengembangkan eksistensi dengan memprioritaskan keberanian yang dilandasi integritas dan profesionalitas, tetapi proses penanaman nilainilai bela negara dilakukan dengan intensitas yang menurun.

Maka direkomendasikan agar TNI AU menetapkan Kebijakan Mutu Pendidikan dengan memperkuat sistem manajemen mutu yang tetap mengacu pada landasan filosofis dan ideologis, guna mencapai sasaran program kerja pendidikan yang telah ditetapkan. Kebijakan mutu selain tentang profesionalitas agar lebih memperhatikan pada aspek sikap perilaku seorang combatan. Sehingga kualitas hasil didik memiliki sikap dan perilaku yang didasari nilai-nilai bela negara dengan sikap profesional dan integritas yang tinggi. Untuk itu peneliti menyampaikan beberapa saran sebagai berikut: (a) agar memperkuat landasan historis dan filosofis dengan melakukan reorientasi terhadap penanaman nilai-nilai bela negara Kadet Maguwo; (b) agar meninjau ulang kebijakan yang berlaku dan supaya tetap menjaga intensitas yang tinggi terhadap pelaksanaan pembinaan dan penanaman nilainilai bela negara.

\section{DAFTAR PUSTAKA}

Basrie. (1998). Bela negara implementasi dan pengembangannya. Jakarta: UI Press.

Durkheim, E. (1990). Pendidikan moral, suatu studi teori dan aplikasi sosiologi 
pendidikan. (Judul asli: Moral Education: 1961). Jakarta: Erlangga.

Falconnet, Paul. (1923). The Pedagogical work of Emile Durkheim. (American Journal of Sociology). Chicago: The University of chicago Press.

Fott, David. (2009). John Dewey and the mutual influence of democracy and education. Cambridge University Press.

Fishben. (1975). Belief, attitude, intention and behavior, an introduction to theory and research. Philipines: Addison-Wesley.

Frondizi, R. (1963). What is value. Illinois, US: Open Courtb Publishing Company.

Freire, P. (2007) The Politic of education: culture, power, and liberation. Yogyakarta: Pustaka Pelajar (Cetakan VI).

Hardjosatoto, S. (1985). Sejarah pergerakan nasional Indonesia, suatu analisis ilmiah. Yogyakarta: Liberty.

Kirschenbaum, H. (1995). 100 ways to enhance values and morality. Boston: Longwood Proffesional Book.

Mulder, N. (2000). Individu masyarakat dan sejarah (Edisi Indonesia). Yogyakarta: Kanisius.

Mulyana, R. (2004). Mengartikulasikan pendidikan nilai. Bandung: Alfabeta.
O’Neil, William. (2008). Ideologi-ideologi pendidikan. Yogyakarta: Pustaka Pelajar.

Patching, K, (2007). Leadership, character and strategy. New York: Palgrave Macmillan.

Renan, E. (1994). Apakah bangsa Itu? (Diterjemahkan oleh Prof MR Sunario dari "Qu'est ce Qu'une Nation" (1882). Bandung: Penerbit Alumni.

Ritzer, G \& Goodman, DJ. (2009). Teori sosiologi, dari teori sosiologi klasik sampai perkembangan mutakhir teori sosial postmodern. Yogyakarta: Kreasi Wacana.

Rokeach, M. (1969). Beliefs attitudes and values. San Francisco: Jossey-Bass Inc., Publishers.

Scheler, M. (1954). The Nature of sympathy. London: Routledge \&Kegan Paul Ltd.

Tamburaka, R. (2002). Pengantar ilmu sejarah, teori filsafat sejarah, sejarah filsafat \& iptek. Jakarta: Rineka Cipta.

Wilber, K. (1997). An Integral theory of conciousness (Journal of Conciousness Studies). Imprint Academic. 